\title{
Determining the Antecedents of Actual Purchase of Local Product Brand in Yemen
}

\author{
Jamal Mohammed Esmail Al-Ekam¹, Nik Kamariah Nik Mat ${ }^{1, *}$, Salniza Md. Salleh², \\ Habibu Mohammed Umar ${ }^{1}$, Musa Ewugi ${ }^{1}$, Anas Salameh ${ }^{1}$, Abu Nurudeen ${ }^{1}$ \\ ${ }^{1}$ Othman Yeop Abdullah Graduate School of Business, Universiti Utara Malaysia, Sintok, 06010, Malaysia \\ ${ }^{2}$ College of Business, Universiti Utara Malaysia, Sintok, 06010, Malaysia
}

\begin{abstract}
This study is meant to examine the relationships of several antecedents of actual purchase of local products in Yemen. Actual purchase is considered a vital link to a business success. The study identified four antecedents of consumer actual purchase. Namely; patriotism, quality, masculinity culture and government support. A total of 287 respondents (about 70\%) completed and returned the questionnaire. A seven point liker scale was used to measure responses. The data were analysed using Structural equation modelling (SEM), using AMOS version 16. Confirmatory factor analysis of measurement models indicates adequate goodness of fit after a few items were eliminated through modification indices verifications. Goodness of fit indices of the revised structural model show adequate fit. The goodness of fit indices of the revised model indicate adequate fit (GFI=.967, RMSEA=.034, RATIO CMIN/DF=1.327, P-VALUE=.061). The regression parameter estimates of three variables are found to be significant at $5 \%$ level of significance. Contrary to our expectation, the mediating role of intention to actual purchase could not be established in this study. The findings are discussed in the context of actual and intend purchase of local brands in Yemen.
\end{abstract}

Keywords Actual Purchase, Intention, Patriotism, Masculinity Culture, Government Support, Yemen

\section{Introduction}

This study empirically investigates the impact of intention, patriotism, quality, masculinity culture and government support on actual purchase of local products in Yemen. Actual purchase behavior implies the willingness and ability of the consumers to buy a commodity or service. Similarly, Actual purchase behavior of local products/brand is seen as the attitudes of the consumers in different parts of the world, having different abilities in terms of actual purchase, to select between local and foreign products/brands According to Kotler and Armstrong[1], there is a low 'actual purchase' of locally produced goods (local brand) in Yemen as evidenced by the increase in the quantity of imported foreign products. The importation rate increased by $14.1 \%$ from 2006 to 2007 and $12.3 \%$ from 2007 to 2008[2]. Similarly, $\mathrm{Al}-\mathrm{Smeh}[3]$, reported that, the Yemen government is spending $\$ 2$ billion annually to import foreign products while the same or similar products are produce locally. As a result, the country's terms of trade are always deteriorating, weakening the domestic production and led to closure of many businesses.

\footnotetext{
* Corresponding author:

gamal_mohammed2003@yahoo.com (Jamal Mohammed Esmail Al-Ekama) Published online at http://journal.sapub.org/economics

Copyright (C) 2012 Scientific \& Academic Publishing. All Rights Reserved
}

Consequently, some Yemeni companies 4.5\% (50 companies) went bankrupt in 2007, 2008[2]. 'Ever since Yemen opened its market to foreign products, local firms have been faced with stiff market competition from outside and local production became non-progressive. Consequently, this led to the incapability of the local industries to cope with competing foreign products and many firms went into bankruptcy'[4]. Thus, It is important to ask why consumers in a particular country go for foreign products as against the locally produced ones? Understanding purchase behaviour is therefore very important in order to attract and retain consumers. Thus, marketers need to keep improving their understanding of consumers' behaviour both from an individual's perspective and also in terms of market sector. It will also provide useful inputs to policy making and implementation.

In advanced countries, consumers are inclined to purchase their local products but in the developing and the less developed countries, consumers usually prefer imported products. This is the case with Yemeni consumers hailing from Yemen. Some researchers attributed such a behavior with a belief among consumers (most especially consumers from developing countries) that local products are not as good as the foreign imported ones. In line with this, several authors confirmed that consumers in a developed economies have a tendency to purchase domestic product first, followed by products from similar level of developed economy, and 
then goods from less developed countries[5],[6],[7].

The literature on the determinants of actual purchase behavior is vast. Different researchers explored the role of different variables on actual purchase in various places. For example, the following researchers have found positive and significant effects of the following factors; ethnocentrism and demographic factors[8]; ethnocentrism, national identity, nationalism and cultural openness [9] relative product quality, ethnocentrism and patriotism[10] ethnocentrism, patriotism, social concern, responsibility, costs, similarity and common fate[11], patriotism, country image and service ability[12] country of origin, ethnocentrism, and demographic factors; country of origin, brand and price[5].

Most of these studies are carried out in advanced countries and middle income countries which may have differing institutional, environmental and cultural features from Yemen. We follow the approach of these studies, but improved the model with some additional variables peculiar to the economy of Yemen. The findings of the study can provide insights for both policy makers and marketers alike, on the key variables that could be used for promoting more widespread consumption of locally produced goods in the country.

\section{Literature Review}

One of the leading theories that inform studies on consumer behaviour is the Theory of Planned Behaviour (TPB). The central idea of the theory holds that; peoples' intention to perform a behaviour is influenced by a combination of the following factors: behavioural attitudes (i.e. a person's beliefs about the desirability of behaviours); subjective norms (i.e. a person's perceived relevance and importance of opinions of significant others); and behavioural control (i.e. a person's sense of control over behaviour)[13] .

An individual's attitude or behaviour towards consuming a product is one of the most important antecedents for predicting and explaining consumers' choices across products and services, including brand (i.e. local or foreign) products[14]. Jung[15] defines attitude as a psychological construct which represents an individual's readiness to act or react in a certain way. It is a relatively enduring evaluation of an object against alternatives, and is based on an individual's thoughts (cognition), beliefs (values) and emotions (affection) towards the object[16];[17].

Individuals with high sense of patriotism always put their country first before others, irrespective of any other considerations. This belief may also reflect their consumption habits and make them purchase local products against the imported goods. It is therefore hypothesized that;

H1: patriotism is likely to strengthen the individual's intention to purchase a local brand.

Quality is another reason why consumers patronise a particular product or service. Quality may be seen as the ability of the product to yield maximum satisfaction to the consumers. This can take the form of durability. The extent that a product is perceived to be qualitative by the consumers the more it will therefore influence the intention to consume the product. Hence, it can be hypothesized that;

$\mathrm{H} 2$ : Quality of a product will positively impact the willingness to purchase that product.

However, government support can influence the demand of a given product in country. Supports given to local producers in terms of production subsidy or tax holidays can lower the prices of the locally produced goods; consequently, this can boost the peoples' intention to by more of the goods. This leads us to the third hypothesis;

H3: Intention will positively impacts actual purchase.

\section{Methodology}

Four hundred and ten questionnaires were distributed to the selected consumers in Sana'a the capital city of Yemen. The respondents were randomly selected and cut across different income groups and age brackets. Sana'a being the capital city is thought to be a good representation of the larger Yemen because people from any parts of Yemen are found there.

A sample of 287 was returned ( $70 \%$ response rate) and used for data analysis after filling in some missing values and data transformation for ensuring normality of distribution.

The statistical approach employed in this study is structural equation modelling (SEM) in assessing the fitness of the data to the model. In building the model, five factors are identified as independent variables (exogenous), namely; intention, patriotism quality, masculinity culture and government support. The dependent variable (endogenous) is actual purchase. The aim is to assess the causal effects of the listed independent variables on the dependent variable (actual purchase). The indices of fitness selected as reference for evaluating the adequacy of the model were the Chisquare statistics, Bentler-Bonett Non-Normed Fit Index (NNFI), Comparative Fit Index (CFI), and Goodness-of-fit Index (GFI). These indices were provided by AMOS and commonly selected for assessing a model's goodness-of-fit. There was also a general agreement that a GFI index greater than 0.90 and close to 0.95 should be an indicator of an adequately fitted model[18] .

\section{Findings}

Structural equation model was used for exploring the impact of exogenous variables on actual purchase intention of actual purchase in Yemen. Consistent with the TPB theory, the exogenous constructs were modelled to impact intention directly, and actual purchase indirectly. The revised model (Figure 1) achieves significant improvements in terms of its goodness-of-fit indices as all suggested values were met after some adjustments were made (Ratio = 1.327 ; GFI $=0.967 ; \mathrm{p}$ value $=0.061 ; \mathrm{RMSEA}=0.034)$. 
Patriotism has a significant direct positive effect actual purchase $\left(\beta=0.372^{* * *}\right)$. Hypothesis $\mathrm{H} 1$ which proposed that patriotism would positively impact willingness to buy local products could not be rejected. Quality has a significant albeit weaker direct positive effect on Actual purchase $\left(\beta=0.279^{* *}\right)$. Therefore, hypothesis $\mathrm{H} 2$ which proposed that perceived quality of a product will influence willingness to buy or not to buy a product could not be rejected. The coefficient of Intention is also found to be positive and significant at $5 \%$. This is consistent with the TPB theory which proposes behavioural intention as an antecedent of actual behaviour.

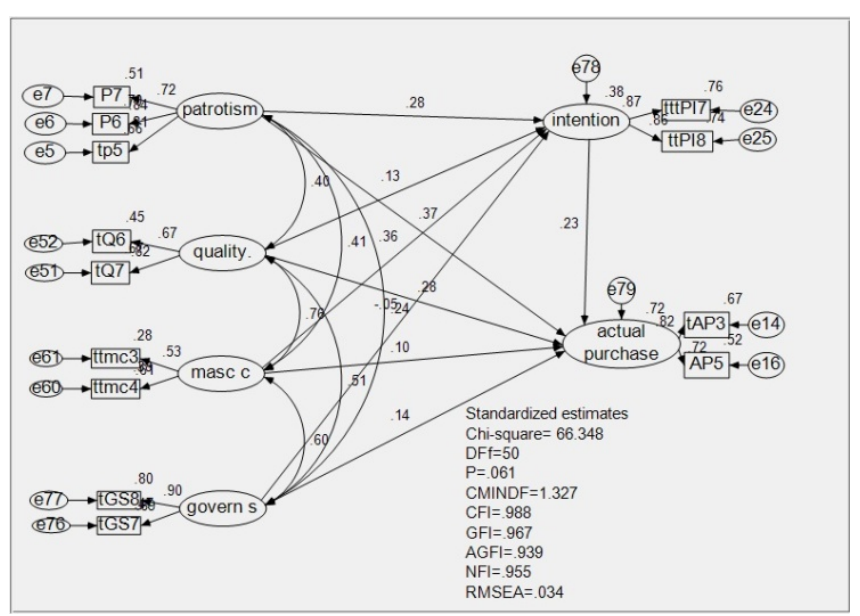

Figure 1. The Revised Structural Model

\section{Discussion}

The findings from this study offer insights on the consumption behaviour of the Yemenis towards local products brand. To promote the market of local products brand among the people of the country, government should encourage high level of patriotism among its citizens. Producers and relevant government agencies alike may extend their influence over contextual factors that shape consumer attitudes towards local products brand. Awareness campaign on the relative economic advantage of consuming locally made products can help. Similarly, government should come up with more policies that will be supportive to the local producers. These may include policies like; tax holiday to existing local firms, import duties on consumer goods, production subsidies etc. These inevitably contribute towards enhancing intention and actual to consume local products brand.

\section{Conclusions}

In conclusion, this study manages to establish three significant paths (three hypotheses are supported), patriotism to actual purchasing, perceived quality to intention and intention to actual purchase. Masculinity and government support have no significant impacts on both behaviors (intention and actual).

Table 1. Parameter Estimates Of The Revised Structural Model

\begin{tabular}{|c|c|c|c|c|}
\hline Relationship & Estimate & S.E. & C.R. & P \\
\hline Quality $\rightarrow$ intention & 133 & 216 & 775 & 439 \\
\hline $\begin{array}{c}\text { Masculinity culture } \rightarrow \\
\text { intention }\end{array}$ & 364 & 402 & 1.563 & 118 \\
\hline $\begin{array}{c}\text { Government support } \rightarrow \\
\text { intention }\end{array}$ & -.049 & 144 & -.485 & 628 \\
\hline $\begin{array}{c}\text { patriotism } \rightarrow \text { actual } \\
\text { purchase }\end{array}$ & 372 & 013 & 5.304 & $* * *$ \\
\hline Quality $\rightarrow$ intention & 279 & 142 & 2.083 & 037 \\
\hline $\begin{array}{c}\text { Masculinity culture } \rightarrow \\
\text { actual purchase }\end{array}$ & 095 & 268 & 519 & 604 \\
\hline $\begin{array}{c}\text { Government support } \rightarrow \\
\text { actual purchase }\end{array}$ & 138 & 101 & 1.644 & 100 \\
\hline $\begin{array}{c}\text { intention } \rightarrow \text { actual } \\
\text { purchase }\end{array}$ & 229 & 067 & 2.893 & 004 \\
\hline
\end{tabular}

\section{ACKNOWLEDGEMENTS}

We would like to thank Prof Dr. Nik Kamariah Nik Mat and Sukma Pea for their helpful comments and assistance on an earlier version of this paper.

\section{REFERENCES}

[1] Kotler, P., and Armstrong, G.(2009). Marketing Essentials, New York: Prentice Hall.

[2] Yemen Economic Report (2008) www.comtrade.un.org, Central Bank of Yemen annual report, 2008.

[3] Al-Smeh,Abdul Hafiz (2010) Cabinet Secretary-General, Monday 29-March-2010, Alomtamer net.

[4] Yemen Economic Report 2008 www.comtrade.un.org)

[5] Zafar U. A, Johnson P. J, \& Boon, L. C,(2004),. Does country of origin matter for low-involvement products? International Marketing Review. Vol. 21 No. 1, 2004.pp. 102-120. Emerald Group Publishing Limited.

[6] Wall, M. and Heslop, L.A. (1986), "Consumer attitudes toward Canadian-made versus imported products", Journal of the Academy of Marketing Science, Vol. 14 No. 2, pp. 27-36.

[7] Wang, C.K. and Lamb, C. (1980), "Foreign environmental factors influencing American consumers' predisposition towards European products", Journal of the Academy of Marketing Science, Vol. 8 No. 4, pp. 345-67.

[8] Nazlida, M. H \& Razli, C. R, (2004). “ Consumer Ethnocentrism: The Relationship With Domestic Products Evaluation And Buying Preferences ".IJMS 11(SPECIAL ISSUE), 29-44(2004).

[9] Lrena Vida and James Reardon (2008) "Domestic consumption: rational, affective or Normative choice?", Journal of Consumer Marketing 25/1 (2008) 34-44 q Emerald Group Publishing Limited[ISSN 0736-3761.

[10] Granzin, K, Janeen E. and Olsen, (1998), “Americans’ Choice of Domestic over Foreign Products: A Matter of Helping Behavior? ”, Journal of Business Research 43, 39-54 ã 1998 
Elsevier Science Inc.

[11] Lrena Vida, Tanja Dmitrovic and Claude Obadia, (2008) "The role of ethnic affiliation in consumer ethnocentrism" European Journal of Marketing Vol. 42 No. 3/4, 2008 pp. 327-343. In Bosnia and Herzegovina.

[12] Han, C.M. and Terpstra, V. (1988), "Country of origin effects for uni-national and bi-national products", Journal of International Business Studies, Vol. 19 No. 2, pp. 235-55.

[13] Ajzen, I. (1991). The theory of planned behavior. Organizational Behavior and Human Decision Processes 50: 179-211.

[14] Honkanen, P, B. Verplanken, and S. O. Olsen. (2006). Ethical values and motives driving organic food choice. Journal of Consumer Behaviour 5(5): 420-430.

[15] Jung, C.G. (1971). Psychological Types, Collected Works, Volume 6. Princeton, NJ:Princeton University Press.

[16] Hoyer, W.D. and D. J. Maclnis. (2004). Consumer Behavior. Boston: Houghton Mifflin.

[17] Dossey, B.M. and L. Keegan.(2009). Holistic Nursing: A Handbook for Practice, Sadbury, MA: Jones and Bartlett Publishers.

[18] Hair, J., Money, A., Samouel, P., \& Page, M. (2007). Research methods for business: John Wiley and Sons Ltd. 